\title{
Prolonged Stabilization of Amyotrophic Lateral Sclerosis (ALS) with a Specially Fermented Soy Product (FSWW08): Case Report and Discussion
}

\author{
Kimberley Goslin ${ }^{1}$, Adolf E. Schindler ${ }^{2}$ and Uwe D. Rohr ${ }^{3, *}$ \\ ${ }^{1}$ Providence Portland Medical Center, Portland, Oregon, USA \\ ${ }^{2}$ Institute for Medical Research and Education, Hufelandstrasse 55, 45122, Essen, EU, Germany \\ ${ }^{3}$ The Vienna Stress Relief Clinic, Spiegelgasse 2a 1010 Vienna, EU, Austria
}

\begin{abstract}
Amyotrophic lateral sclerosis (ALS) is typically characterized by adult-onset degeneration of the upper and lower motor neurons in mostly male patients, and is usually fatal within 2 to 5 years and is by definition a progressive disease. Only one drug, riluzole, has been approved to treat ALS, which typically provides only a gain of survival of a few months. The exact etiology of ALS isn't known. However most researchers suggest, that ALS increases inflammation and increases cellular stress so that arriving stem cells and local stem cells cannot differentiate into functional nerve cells: ALS shares on a genetic level many similarities with cancer resistance and supports the view that tissue repair and cancer are related. Deteriorating general immunity in nerve cells causes dementia, mental stress, and anxiety. A fermented soy formulation (FSWW08) has been shown to improve local and general immunity in cancer patients and reduces stress on the molecular as well as a clinical level: FSWW08 improved on the genetic molecular level MAPkinase, c-Jun, and NF-kB, which are impaired in ALS patients. A 50 year old man diagnosed two years ago with ALS in the neck was given one month later over a two year period standard therapy, standard physical care, riluzole antiinflammatory drugs, oxybutynin for urge incontinence, and additionally FSWW08. Three month before being diagnosed with ALS; the patient suffered from severe mood swings (anxiety disorders but not depression), which were treated by a psychiatrist. The patient complained about severe sleeping disorders at that time. Improvement of mental and physical well-being of FSWW08 was documented by two questionnaires specifically developed for ALS (Amyotrophic Lateral Sclerosis-Frontotemporal Dementia-Questionnaire [ALS-FTD-Q]) and a quality of life questionnaire from the ESQR questionnaires. The progress of local muscle impairment in the neck, which caused the disease, was stopped after 2 month of consumption of FSWW08, as well as breathing being stabilized at a low, but stable levels above the defined level for obstructive disease. Strong on/off fluctuations of ALS symptoms were observed and documented with the consumption of FSWW08, standard medication was continued and had no effect on on/off motor functions of ALS. When the consumption of the FSWW08 was stopped motor dysfunctions of the arms reappeared within two weeks and the patient lost his ability to speak. When consumption of FSWW08 was resumed the disturbances disappeared within 7 days. Additionally it was observed that immune disturbances, hay fever and usual infections during winter, were completely eliminated. Under FSWW08, mental stress and anxiety was reduced, accompanied by a normal sleeping pattern at night and increased energy levels, which caused increased physical activity. Patient reported improved breathing, documented by stable FVW. The patient exhibited a normalization of blood pressure (from pre diagnosed ALS and no consumption of FSWW08, similarly in the off phase, when FSWW08 was not taken) from 170/100 mm HG to 120/80 mm HG under FSWW08 consumption) within seven days, blood lipids were normalized (cholesterol, triglycerides, $\mathrm{HDL}, \mathrm{LDL}$ ). It is reported in the literature that unfavorable blood lipids are related to severity of ALS in Japanese and Western patients. This is the first time stabilization of ALS has been observed accompanied by improvements in blood lipids in patients. This single report corroborates studies conducted with FSWW08 in other diseases including cancer, severe mental diseases (PTSD and Schizophrenia) and severe virus infections. The FDA has granted a general unspecific Health Claim that soy improves blood lipids like cholesterol and triglycerides. This is the first time a fermented soy formulation, FSWW08, has prevent progression of ALS over a two years period and normalized blood lipids. The special fermentation of FSWW08 causes an increase in immunity, cellular stress reduction and blood lipids. Larger clinical trials in ALS patients with FSWW08 are now warranted to investigating whether these results can be confirmed, and whether FSWW08 increases survival, as well as whether blood lipids are a prognostic marker of ALS.
\end{abstract}

Keywords: Amyotrophic lateral sclerosis, neuro-degeneration, motor neuron disease, genetics, FSWW08, dyslipidemia, triglyceride, cholesterol.

\section{INTRODUCTION}

Amyotrophic lateral sclerosis (ALS) - also referred to as motor neuron disease or as Lou Gehrig's disease in North America - is a debilitating disease with varied etiology characterized by rapidly progressive weakness, muscle atrophy and fasciculation's, muscle

*Address correspondence to this author at the Vienna Stress Relief Clinic, Spiegelgasse 2a 1010 Vienna, EU, Austria; Tel: 00436889072192;

E-mail: uwerohr@googlemail.com spasticity, difficulty speaking (dysarthria), difficulty swallowing (dysphagia), and difficulty breathing (dyspnea) [1-7].

The exact etiology of ALS isn't currently known, however, increasing evidence suggests a role for the immune system $[8,9]$. The natural balance between aged local neuronal cells and tissue repair from arriving bone marrow stem cells is controlled by the immune system [10]. The degree of post-injury inflammation of the damaged area of a spinal cord is the main 
difference between the natural successful repair and unsuccessful repair [10], because autoreactive $T$ cells suppresses arriving bone marrow mesenchymal stem cell trans differentiation to local neural stem cells [10]. Cross talk between systemic immunity and local immunity is discussed, because ALS patients also suffer from similar inflammation in other organs, like the liver [11-13] or brain [14] and suffer from lower body mass index prior to death [15].

Co-morbidities of ALS includes increased cardiovascular risk [16], hypertension [17], increased cholesterol, triglycerides and LDL (Figure 1) [18], reduced well-being and increased depression [19], and other immune related disease like arthritis [20], infections and sepsis [21].

Since riluzole is the only approved treatment for ALS, researchers look into the possibility to use plant based formulations for ALS, like curcumin [22] or Ginkgo biloba [23]. The fermented soy formulation, called FSWW08, showed immunity increasing properties in treatment resistant cancer patients [2427], in Hepatitis B virus infections and in soldiers suffering from treatment resistant PTSD [28]. FSWW08 did specifically a) increase immunity in severely compromised patients (Figure $\mathbf{2 b}$ ) increased well-being and reduced stress, as well as c) improved markers with severe metabolic diseases [28] (Figure 2) and d) increased cortisol [28], a steroidal hormone which is a marker for cellular stress, and is decreased in ALS [29].

Previous serological studies suggested distinct profiles of lipid, urate and ferritin levels in sera of European, Israeli and North American patients with ALS (Figure 1) [30-35]. Lipid markers for ALS are sometimes misleading if you detect lipid parameter at early stages of disease or at late stages of disease.
Severity of ALS is related to increased cardiovascular risk parameters related to metabolic diseases [30]. In some studies, however, survival of ALS seems to be related to an increase of lipid parameters, which seems to be more of a malnutrition problem, because starvation will decrease lipid parameter [36, 37]. At late stages of ALS, patients tend to lose weight due to malnutrition, which always decreases blood lipids [38].

FSWW08 normalizes dyslipidemia (Figure 3) [24, 28], FSWW08 silences, at the genetic level, the gene expressions related to immunity (Figure 2), particularly Map kinase and NF-kB (Figure 2) [26-27], which are also unfavorably up-regulated in ALS patients, specifically c-jun, MAP-kinase cascade and NF-kB [3944]. The MAP-kinase seems to play a critical key role in disease progression in ALS [47], which is silenced by FSWW08 in cancer patients [27].

Therefore the treatment attempt with FSWW08 was not only intended to improve well-being or nutritional status, which is recommended by many researchers to correct the unfavorable blood lipids, but the hope was also generated that a stabilization of ALS could be obtained, since cancer and ALS show similar genetic immune pattern: The similarity between cancer, muscle disease and some immune disease has long been discussed by scientists [47-51]. Since FSWW08 did improve immunity, survival in cancer patients, an exploratory try in ALS is warranted to the efficacy over a two-year period.

\section{METHOD}

\section{ALS Questionnaire}

The ALSFRS-R is a revised ALS functional rating scale to test also respiratory function [52]. The increase
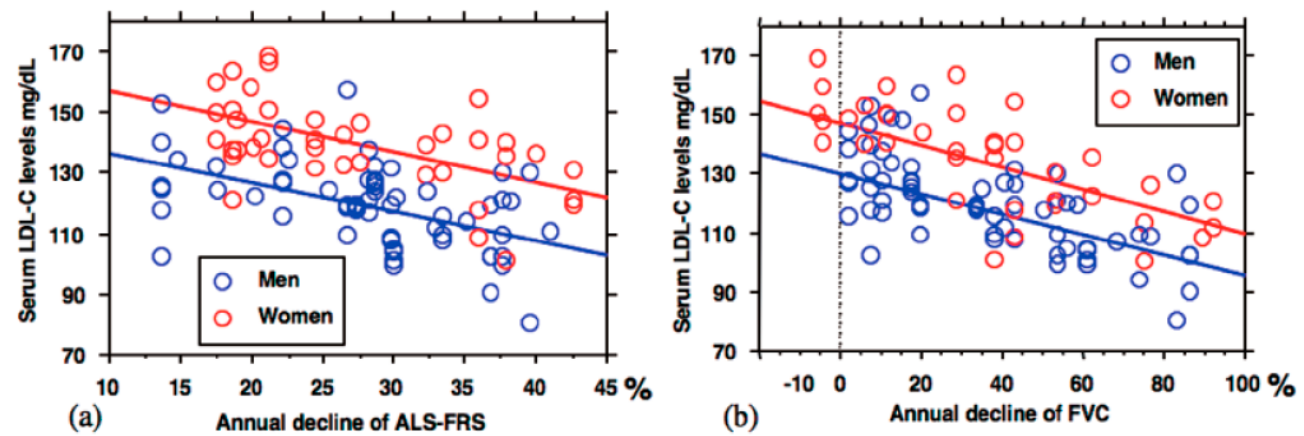

Figure 1: Relationship between Disease Progression and Serum Lipid Levels. (a) The inverse correlation between serum LDL-C and the annual decline of ALS-FRS. Male patients (blue line): Spearman rho correlation $=-0.46(p<0.01)$. Female patients (red line): Spearman rho correlation $=-0.51(\mathrm{p}<0.01)$. (b) The inverse correlation between serum LDL-C and the annual decline of FVC. Male patients (blue line): Spearman rho correlation $=-0.59(p<0.001)$. Female patients (red line): Spearman rho correlation $=-0.51(p<0.001)$. Taken from [30]. 

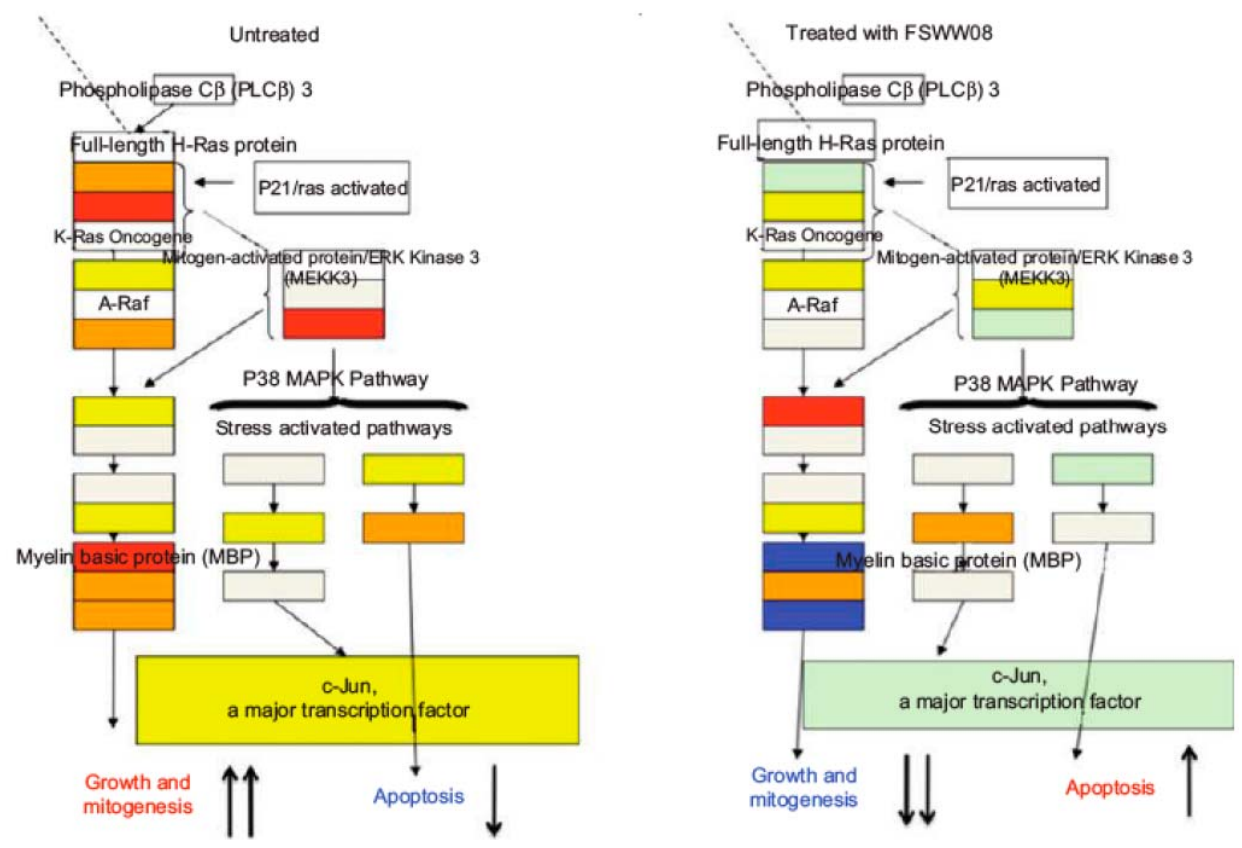

Figure 2: Gene expression changes by fermented soy (FSWW08) on blood circulating tumor cancer cells from breast cancer, before and after consumption of FSWW08: $\square \quad x>2$, $\square 1.5<x<2, \square \quad 1.0<x<1.5$, $\square$ no change, $1>x>0.66$, $\quad 0.66>x>$ $0.5, \square \times<0,5$. (taken from Ref. [26]).

\section{Individual Blood Lipid Marker of Veteran- Soldiers Suffering from PTSD, before and after Consumption of FSWW08}
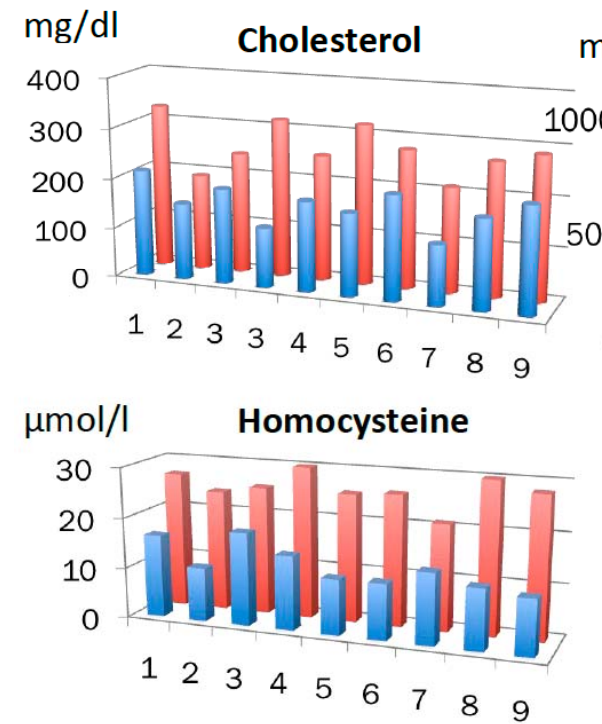

$\mathrm{mg} / \mathrm{dl}$

Triglyceride

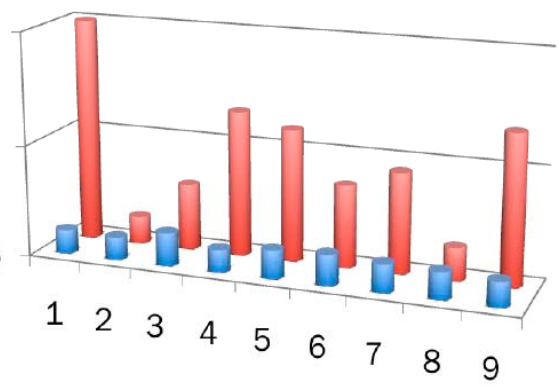

Before

after 3 month consumption of FSWW08

Figure 3: Individual blood lipid marker of veteran soldiers suffering from PTSD, before and after 3 months consumption of FSWW08, (taken from ref. [28]). Cholesterol and triglycerides, two forms of lipid that circulate in your bloodstream, are both necessary for life itself. But when blood levels increase upper levels, they are related to increased cardiovascular risk. Homocysteine is a marker for cardio-vascular and thrombo-embolytic disease [58]. FSWW08 did reduce in all cases markers of cardiovascular diseases in blood.

in ALS symptoms is depicted as a reduced fraction from 48, which indicates no ALS motor disturbances [52]. ALSFRS-R scores correlate significantly with quality of life.
The ALS-FTD-Q is a new screening tool for behavioral disturbances in ALS, particularly frontotemporal dementia is depicted [53]. 
Since both questionnaires were designed to depict the progress of ALS, and no treatment exists to modify mental symptoms in ALS, additionally the EORTC QLQ-C30 questionnaire was used, which is a questionnaire formally used for cancer, but is also used in head and neck cancer treatment [53]. The impact of nutrition in head and neck disease has been depicted with this questionnaire in the literature [53].

\section{Measuring Lung Functions}

The FEV1/FVC ratio, also called Tiffeneau-Pinelli index, is a calculated ratio used in the diagnosis of obstructive and restrictive lung disease [55-56]. It represents the proportion of a person's vital capacity that they are able to expire in the first second of expiration. Normal values are approximately $80 \%$. Predicted normal values can be calculated online and depend on age, sex, height, weight and ethnicity as well as the research study that they are based upon.

\section{Study site}

The study was conducted at the Oregon Clinic, Neurology Division, 5050 NE Hoyt Suite 315, Portland OR 97213. Due to the severity of the disease and to standard procedures, the patient received support from several institutions affiliated to the Oregon Clinic, like massage therapists, social support groups and other medical facilities experienced with neurological muscle diseases.

\section{Personal Data}

The male patient was born on April 22, 1962. He was diagnosed with amyotrophic lateral sclerosis, ALS, on April20, 2011.

\section{RESULTS}

The patient was in normal health throughout his life. In the past, he had experienced only knee surgery in 2002 due to arthritis. At the time of diagnosis, the patient suffered from hypertension and metabolic disease, particularly hypertriglyceridemia and hypercholesterinaemia, breathing problems, and excessive mood swings (Figures 4-7) and hay fever. In 1987 he fell from a two-story ladder and suffered head and neck injuries. The patient was also involved in a car accident, which impacted his upper part of the body. What caused ALS can only be speculated. No muscle disease was ever been detected in his family, therefore it is assumed that the fall from the ladder caused local inflammation and a long-term defect, which ultimately developed into ALS.

\section{Breathing Pattern of an ALS Patient}

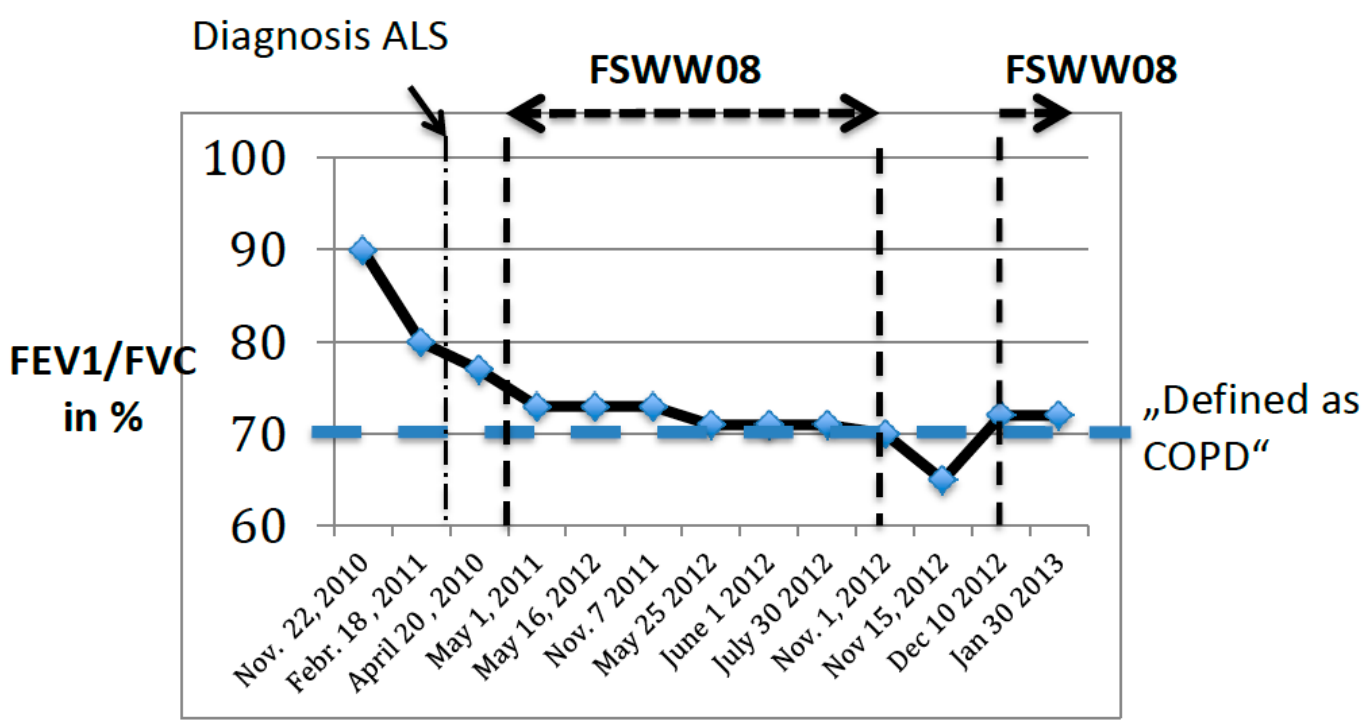

Figure 4: Breathing Pattern of a man, who was diagnosed on April 10, 2011 with ALS. He received FSWW08 a fermented soy product and the decay of breathing was stabilized, judged as FEV/FVC, The FEV1/FVC ratio, also called Tiffeneau-Pinelli [1] index, is a calculated ratio used in the diagnosis of obstructive and restrictive lung disease. It represents the proportion of a person's vital capacity that they are able to expire in the first second of expiration [4]. The FEV1/FVC ratio, also called Tiffeneau-Pinelli [1] index, is a calculated ratio used in the diagnosis of obstructive and restrictive lung disease [2, 3] It represents the proportion of a person's vital capacity that they are able to expire in the first second of expiration [4]. FEV1 Forced expiratory volume (time): a generic term indicating the volume of air exhaled under forced conditions in the first $t$ seconds. For discussion see [56]. 


\section{Visit Oct. 22, 2010}

He suffered from muscle weakness (ICD 728.87), hyperlipidemia NEC/NOS (ICD-272.4), hypertension (ICD 401.) and breathing problems (Figures 4, 5, 7). The abbreviations NEC and NOS stand for "Not Elsewhere Classified" and "Not Otherwise Specified. "Due to edema in his lung and leg, he took hydrochlorothiazide to reduce water in the lung and legs, his only medication at that time. The patient complained about muscle weakness in the upper arms, which started half a year earlier, for example, he could not carry his golf bag. His shoulders showed girdle pain in the scapular region. His neck muscles showed also tension and pain. Neck flexors and extensions were moderately weak. He also showed occasional fasciculation in the trapezius, deltoids, and pectoral region. He had moderate weakness at the supraspinatus muscle and increased tinnitus, and pain in the deltoid and biceps on the right. The mental exam showed he is oriented in time, place, and person. His memory is intact for recent and remote events. His language skills are fluent, repeats and names without difficulty, followed complex commands without difficulty. His coordination is intact. Diagnosis of different organs showed in a physical examination:

Exam of the respiratory tract reveals complaints of shortness of breast. Patient complained of hair loss. As a sign of a reduced immune system the patient suffered from repeated allergy and hay fever.
Psychiatry complaints were excessive worry, anxiety attacks, however, denies depression and has thoughts of suicide (Figure 6). The patient received psychiatric treatment for mood swings.

\section{Visit October 13, 2010}

MRI of the cervical spine showed some spondylosis and neuroforminal narrowing bilaterally. Blood tests determined by ARUP Inc. Salt Lake City Utah, did not show alterations in thyroid hormones, anti-GM one antibodies, PTH, SPEP, B1, B6, B12, RPR. Neurology tests by EMG in the right 1stDorlnt, the right AbdPoll Brev, the right FlexPo.Long, the Left Triceps and the Left Supraspinatus showed increased motor unit amplitudes and diminished recruitment. The patient was suffering from hyperlipidemia (Figure 7).

\section{Visit January, 102010}

Cerebrospinal fluid (CSF) of the patient by lumbar puncture was investigated and no sign of inflammation or acute malignancy was found. Visual inspection of slides showed signs of benign lymphocytes.

Visit April 20, 2011

ALS was diagnosed by EMG through progressive upper and lower motor neuron findings, diffuse denervation by EMG, most constantly related with ALS. Riluzole $\left(\right.$ Rilutek $\left.^{\circledR}\right)$.Riluzol, was prescribed, which is the first drug approved by the FDA in the United States for

\section{Syst. Blood Pressure of an ALS Patient}

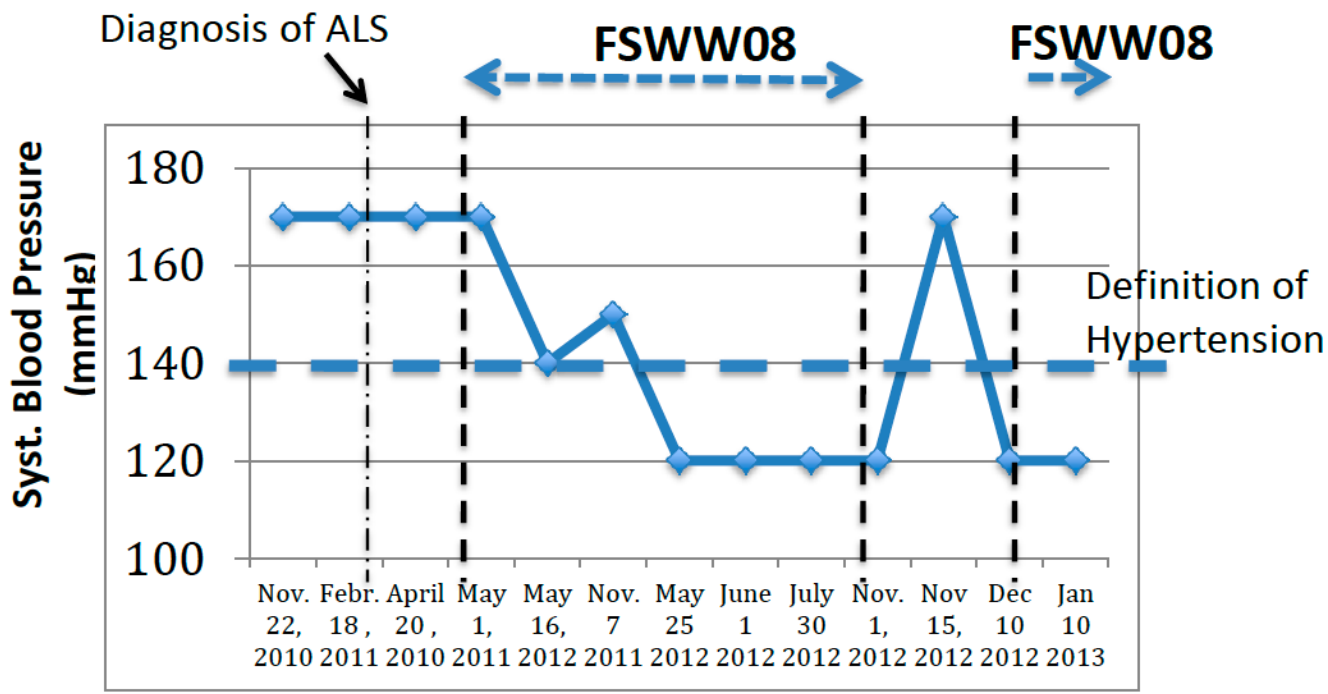

Figure 5: Systolic blood pressure of an ALS patient, diagnosed with ALS on April 10, 2011. During a period of time caused by a compliance problem, the blood pressure increased above an upper limit of $140 \mathrm{mmHG}$. After consumption of FSWW08 was reinstalled, blood pressure was reduced to normal valued again. 


\section{Quality of Life of an ALS Patient}

(determined with EORTC)

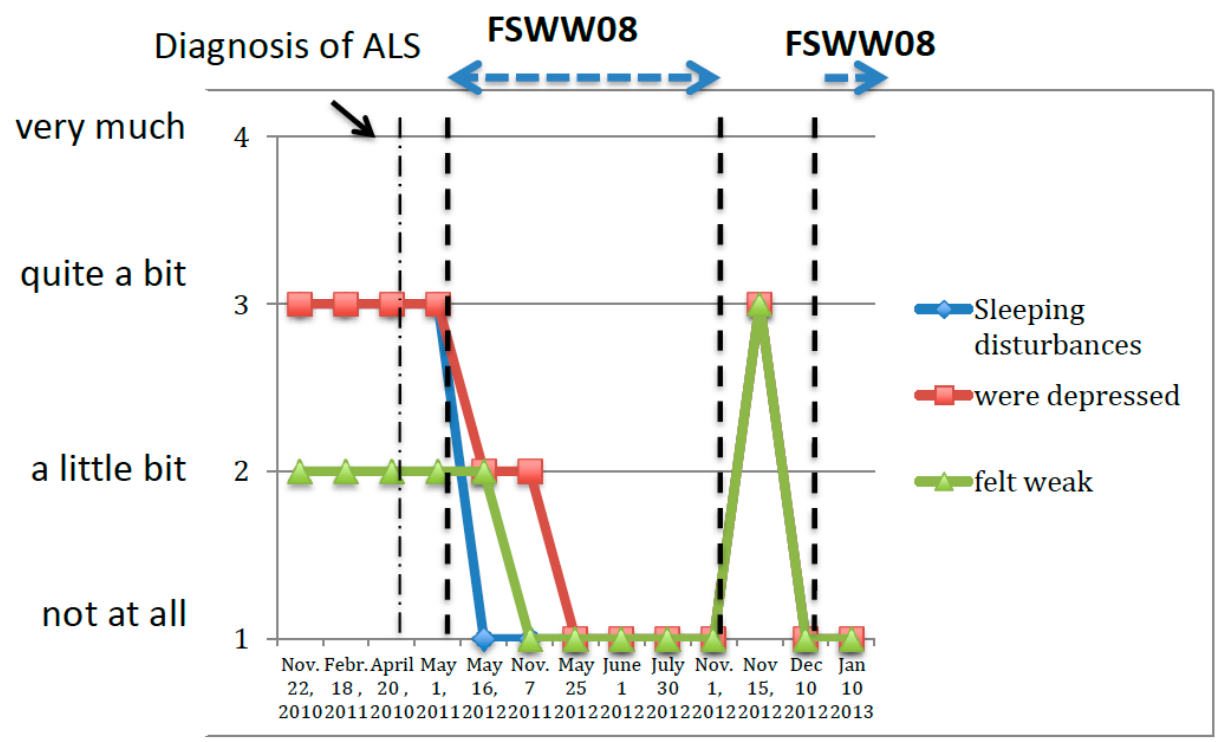

Figure 6: Relationship between quality of life and consumption of FSWW08. listed are answers realted to some questions of the EORTC QLQ-C30 questionanere. Taken from: http://groups.eortc.be/qol/eortc-qlq-c30.

\section{Blood Lipids of an ALS Patient}

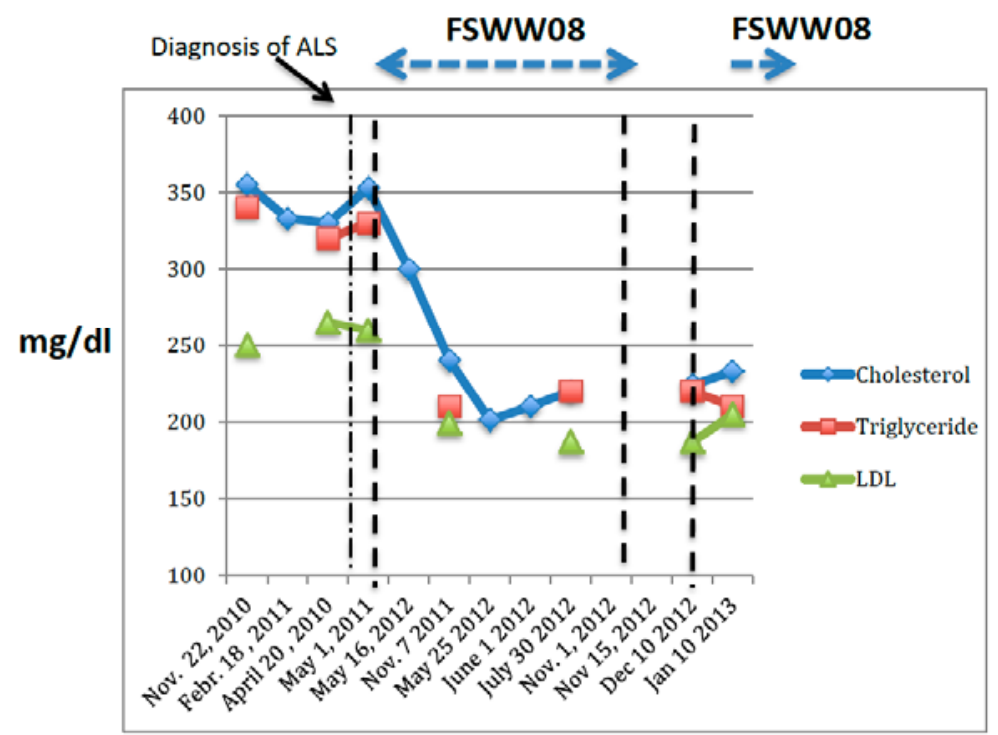

Figure 7: Blood lipids of an ALS patient. After consumption of FSWW08 was initiated the blood lipid parameter were reduced and stayed reduced within normal limits. The patient was diagnosed as hypercholesterimea and suffering from metabolic disease before ALS was diagnosed.

the treatment of ALS. He also took amitriptylineHCL, 10 mg tablets, every 3-4 days as needed for excessive saliva hypersecreation.

The patient consumed additionally the pain reliever Advil $^{\circledR}$ (ibuprofen) for pain relief in his joints. He also took oxybutynin (Ditropan®) to control bladder spasms. Medication was taken constantly. $\mathrm{He}$ was also prescribed amitriptyline, against excessive saliva production.

\section{Visit May 2011}

He started to consume FSWW08, a fermented soy product sold in the US under the name of HAELAN 951, a liquid $225 \mathrm{ml}$ per day. 


\begin{tabular}{|c|c|c|c|c|c|c|c|c|c|c|c|c|c|c|}
\hline 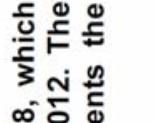 & స్ & $\times$ & + & + & $x$ & $\underset{\infty}{\infty}$ & A & $\stackrel{2}{2}$ & & ণิ ळ & ్ㅡㅁ & $\stackrel{6}{=}$ & $\stackrel{\infty}{\forall}$ & 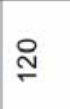 \\
\hline 弦产。 & ญั 웅 눌 & & + & + & $\times$ & $\underset{\infty}{\infty}$ & A & $\stackrel{2}{R}$ & & సิे & $\stackrel{\infty}{\stackrel{9}{\leftrightarrows}}$ & 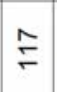 & Z & 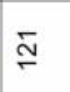 \\
\hline 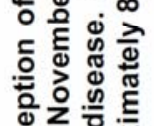 & 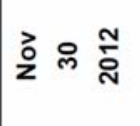 & ż & + & + & $\times$ & 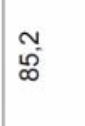 & A & ח & & 홍을 & & & & \\
\hline 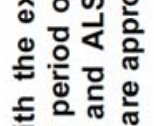 & วัำ & $x$ & + & + & $x$ & 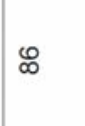 & & & & $\stackrel{\grave{N}}{\stackrel{\circ}{~}}$ & $\stackrel{\infty}{\stackrel{\infty}{\circ}}$ & $\bar{ঙ}$ & $\stackrel{\infty}{\sim}$ & $\stackrel{2}{=}$ \\
\hline 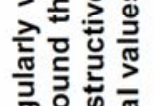 & 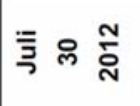 & $x$ & + & + & $x$ & $\begin{array}{l}N \\
\stackrel{\infty}{\mathscr{~}}\end{array}$ & & & & స్ ષ & $\stackrel{\infty}{\infty}$ & $\stackrel{\text { ㅇ }}{\sim}$ & \& & \\
\hline 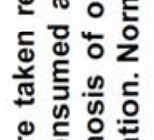 & 施 & & + & + & $x$ & ֻू & & & & $\begin{array}{l}\stackrel{\infty}{\infty} \\
0 \\
0 \\
\underline{0}\end{array}$ & 음 & $\stackrel{\stackrel{m}{r}}{r}$ & & \\
\hline 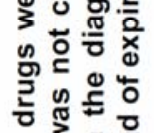 & & $x$ & + & + & $x$ & $\underset{\infty}{\infty}$ & $\stackrel{2}{2}$ & & 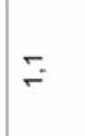 & ১্লি ळ & $\stackrel{\circ}{\circ}$ & $\bar{\Xi}$ & & \\
\hline 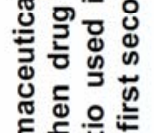 & गิ & $x$ & + & + & $x$ & $\stackrel{\infty}{\infty}$ & ผ & $\kappa$ & & $\begin{array}{l}\infty \\
\infty \\
\stackrel{亠}{\simeq}\end{array}$ & $\stackrel{\circ}{N}$ & $\stackrel{m}{m}$ & $\ddot{8}$ & 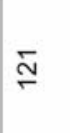 \\
\hline 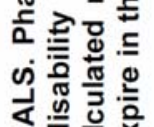 & วัํํำ & $x$ & + & + & $x$ & $\begin{array}{l}\infty \\
\infty \\
\infty\end{array}$ & ผ & $\hat{N}$ & & 항 음 & กั & $\underset{\sim}{J}$ & R & $\stackrel{m}{\stackrel{m}{g}}$ \\
\hline 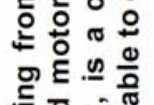 & 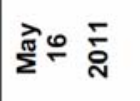 & $x$ & + & + & $x$ & $\tilde{\delta}$ & & $\hat{\imath}$ & & ఫ্ণি৪ & สิ & 吕 & б & 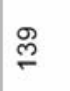 \\
\hline 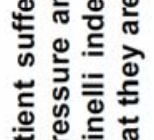 & 市 & $x$ & + & + & $x$ & & & 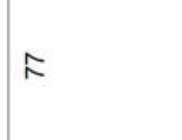 & & & & & & \\
\hline 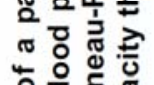 & 춘유 & & & & & \multicolumn{9}{|c|}{ Sา } \\
\hline 当范先 & 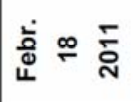 & . & & & & $\hat{g}$ & $\stackrel{\overbrace{}}{\sim}$ & 8 & $\underset{\sigma}{\check{g}}$ & হৃ৪ & 号 & & & ભ \\
\hline 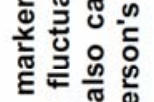 & ํㅗ ส 을 & . & & & & ڤ̈ & $\mathscr{N}$ & 8 & & 응으 & 을 & $\stackrel{\sim}{\sim}$ & $\hat{\infty}$ & ฉి \\
\hline 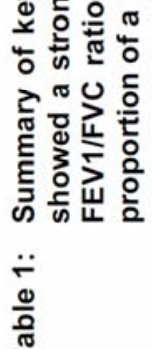 & 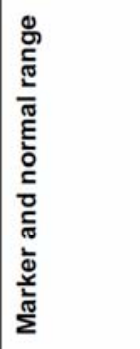 & 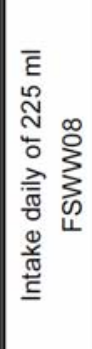 & 点 & 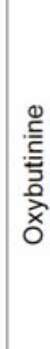 & 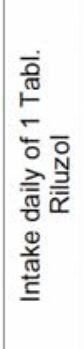 & 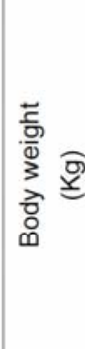 & $\sum_{\infty}$ & 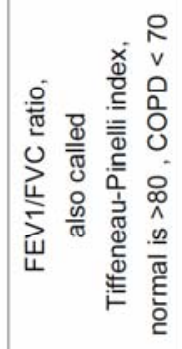 & 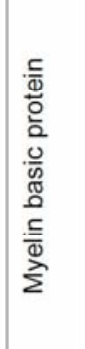 & 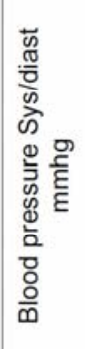 & 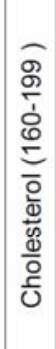 & 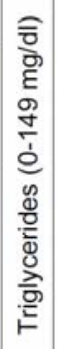 & 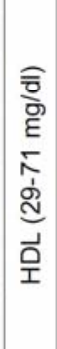 & 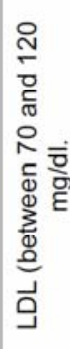 \\
\hline
\end{tabular}




\section{On June 21, 2011}

The ALS patient felt better with regard to breathing and can perform routine work more consistently. Swallowing is fine. The most important change is that he sleeps well for 8-10 hours. Emotions have been improved tremendously, worrying, anxiety and stress have almost disappeared. He eats well. His neck is still weak due to ALS. Legs are still strong and are not affected. The shoulders are slightly weaker from the previous visit. Pain in his joints has disappeared. Patient could reduce the doses of Ditropan due to less spasm and increased urinary frequency. The forced vital capacity (the capacity of strength of his expiratory respirator muscles) was $71 \%$ which is stable since the last visit. The negative inspiratory force (the strength of inspiratory muscle was -45 , which is stable since the last visit (normal is $>-60 \mathrm{~cm} \mathrm{H20}$ ). The peak cough flow was strong and stable at 390 liters/min. The grip strength was stable at 38 kilogram on the left and 29,5 kilogram on the right. The lung function was judged as moderate decrease in inspiratory force.

\section{November 15, 2012}

After returning from a vacation, consumption of FSWW08 was stopped for a month up to December 1, 2012. Severe motor disability symptoms returned immediately after returning home and left and right arm could not be moved anymore. During the period the FSWW08 was not taken the Rilutek was still consumed, but had limited effect in prevent a severe attack of motor disability. Also his ability to speak was completely lost. Additionally, sleeping disturbances were experienced, as well as severe anxiety attacks. The consumption of FSWW08 was installed again, and by the third day the mental disturbances stopped, sleeping disturbances stopped, there was an increased motor ability, and speaking was restored to the level before the FSWW08 was stopped.

Additionally after consumption of FSWW08 was stopped, blood pressure increased to $170 / 110 \mathrm{~mm}$ HG and his mental performance was severely hampered (Figure 6). When FSWW08 was consumed again, blood pressure and mental performance returned to normal values (Figures 5, 6, 7).

\section{December 15, 2012}

The patient is presently in a stable condition, showing mental stability with no worrying, blood lipids are normal again, blood pressure (syst/dias) is normal also and was reduced to $120 / 80 \mathrm{~mm} \mathrm{HG}$ (Figures 5, 6). The pain in the arm and shoulders did not disappear, however is bearable and does not interfere with normal daily routine. The patient is capable to take part in all social activities and can perform normal activities in his house and can dress and undress without help. Patient is experiencing a good quality of life. It can be said that due to the intensive support of the hospital, the general health has improved, for example, no hay fever attack has occurred, prescription of hydrochlorothiazide was stopped, since no edema in lung and legs were detected and no hypertension existed. Patients with emotional stress, and/or, immunity defects normally experience edema and hypertension.

\section{DISCUSSION}

Life expectancy is increasing with the exception in neurodegenerative diseases like Alzheimer, multiple sclerosis, or Morbus Parkinson that lead to dementia and/or paralysis [1-6]. The most deadly disease in this category is amyotrophic lateral sclerosis (ALS), where death occurs within 2 to 5 years after diagnosis [1-6].

The here described open label study suffers from two considerable limitations: Firstly, the study has not included any adequate subjects to evaluate any outcome or hypotheses, and secondly, significant bias and lack of validity in the more subjective outcomes of the study exits, namely patient symptom management: Since the etiology of neurodegenerative diseases are not fully understood and relevant markers have not been established for ALS, yet, any reported finding and correlation of markers in this study have no statistical and may not have medical significance. Contrariwise this single case should be reported and discussed among scientists: The only hypothesis describing the etiology of ALS that has reached general acceptance and seems to be commonly shared in the scientific community is that general and local immunity disturbances facilitates ALS (Figure 8) [1-6]. This one case example obtained in an open label study shows for the first time ever an improvement of several clinical immunological and blood markers, which are discussed to be related to ALS in the scientific literature. Only recently it has been hypothesized that microglia and astrocytes play an essential role in the maintenance of homeostasis within the central nervous system, and may control the magnitude and duration response to infections or injury of cells involved in ALS [77]. Only recently it has been also found that the DHEA metabolite 5alpha-androsten-3B, 17ß-diol (ADIOL) functions as a selective modulator of estrogen receptor 


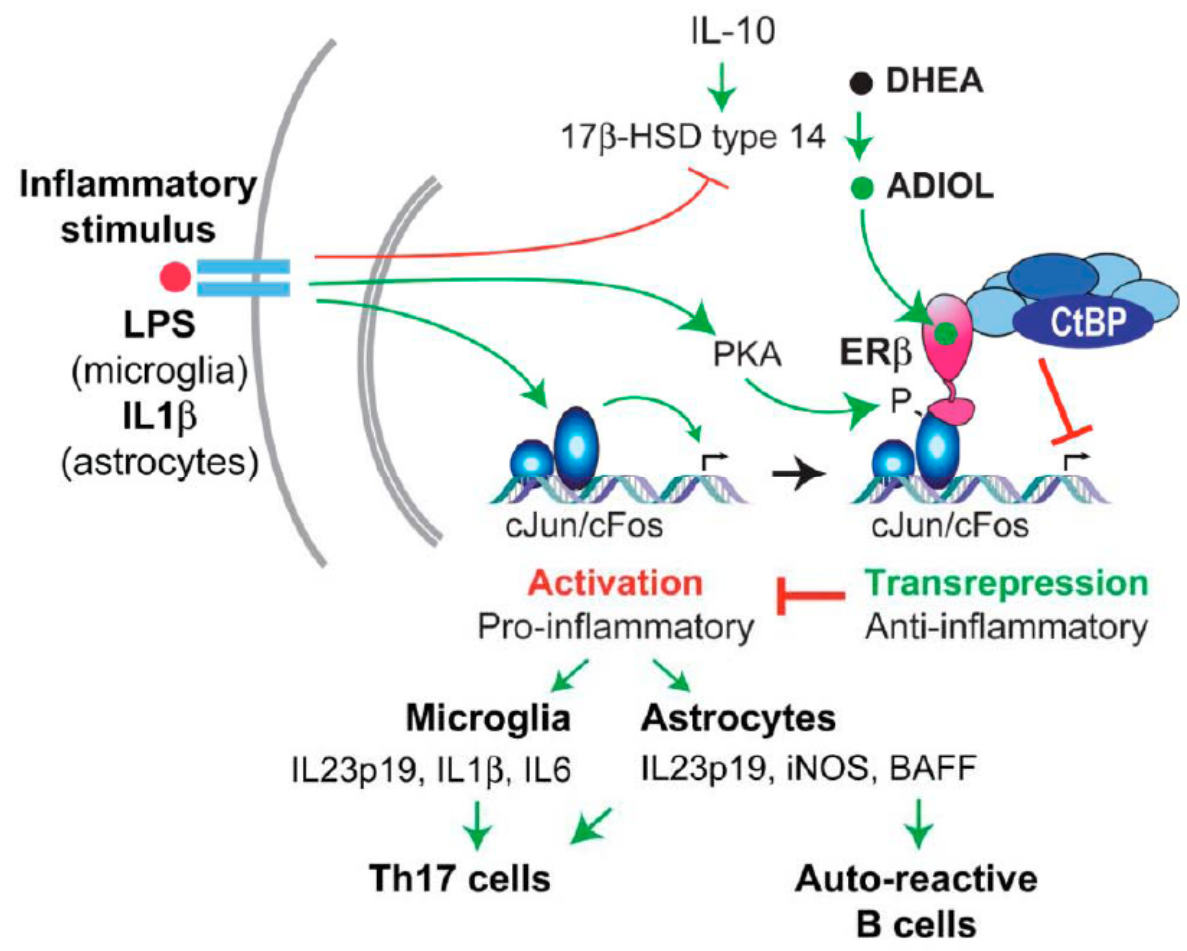

Figure 8: Model for ERß-mediated repression of inflammation of the DHEA metabolite ADIOI is a key sterpod to suppress inflammation in astrocytes. LPS means lipopolysaccharide and is an inflammatory stimulus, IL denotes for cytokines and means interleukin....., ERß means estrogen receptor beta. cJun and cFos are genetic mediators of inflammation. FSWW08 reduces cJun as was shown in Figure 1. iNOS-promotes inflammatory activity, CtBP1 and CtBP2 control the release of the cytokine IL23p19, what promotes inflammation. 17B-HSD type 14 denotes for $17 ß$ hydroxysteroiddehydrogenase, an enzyme that metabolizes the steroidal hormone DHEA into ADIOL. If inflammation occurs then the benefiyial antiinflamamtory ADIOL is reduced. Figure taken with permission from: Saijo et al. CELL 2011145 584-597.

(ER)B to suppress inflammatory response of microglia and astrocytes (Figure 8) [77]. It was hypothesized that administration of ADIOL or synthetic ERß-specific ligant that promote an ADIOL/ERB/CtBP pathway reduce inflammatory responses in microglia and can be targeted by selective ERß modulators and may improve the disease [77].

It is confusing, there are two ADIOLS, which are structurally very similar, are metabolised however, to form two different parent steroidal hormones: the testosterone metabolite 5alpha-androstan-3ß,17ß-diol (the second $A D I O L$ ) are unable to bind to the androgen receptor, however binds to the Estrogen receptor $B$ [66]. Both ADIOLS, the one metabolized form DHEA and the one metabolized from testosterone, show similar pharmacological efficacy, particularly increasing immunity [66]. It has been shown in castrated male mice model that 5alpha-androstan-3ß,17ß-diol is significantly reducing the inflammatory response of the endothelial layer of arteries and as a consequence blood pressure and protecting against arteriosclerosis through the improving blood lipids [78]. Therefore there is a common denominator for arteriosclerosis risk and cellular inflammation, the two steroidal hormones ADIOLs. ADIOLS show strong increase in cellular immunity through modifications in Th1/Th2 cytokines balance [66]. In contrast, however, to cortisones, ADIOLS increase Th2 cytokines, which show strong increase in immunity [66] particularly infections: In this study consumption of FSWW08 has increased general immunity of the ALS patient, for example reduced hay fever, rates of common cold and flu-like infections during winter. A distinct advantage of ADIOLS over cortisones is, that they do not reduce immunity like cortisones, ADIOL can be applied over longer period of times, this is supported by the literature that shows ADIOLS are increased over 6 months during pregnancy without causing side effects in the mother or the baby $[27,66]$.

In this clinical study, consumption of FSWW08 has produced three clinical effects, which are related to increased ADIOL activity: Firstly, increased general immunity of the ALS patient, for example eliminating hay fever, fewer infections during winter, secondly, blood pressure and blood lipids are normalized, and thirdly, motor function of the ALS patient was related to 


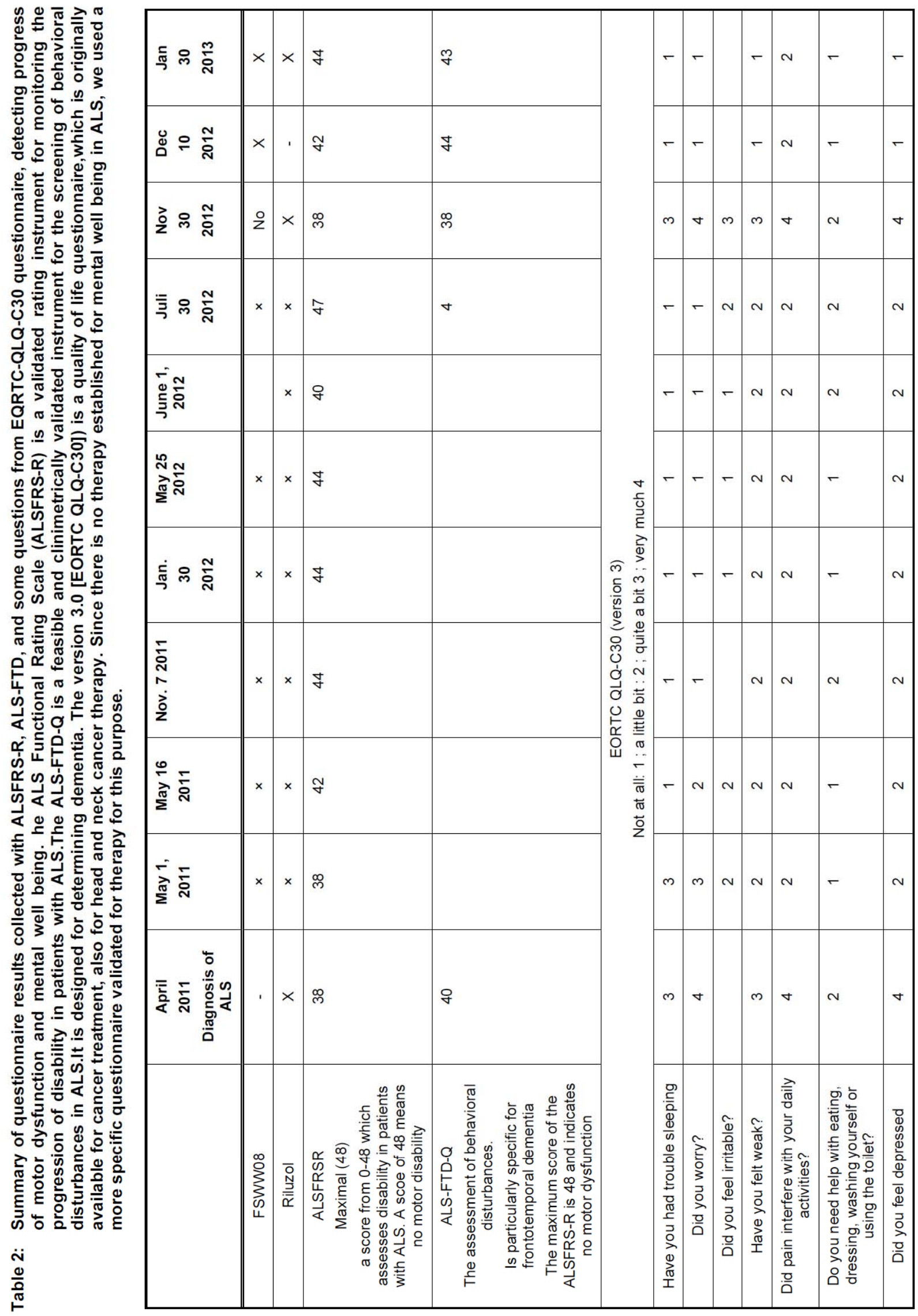


consumption of FSWW09. Besides increasing ADIOLS, other studies show that FSWW08 increases cortisol and testosterone [28], which are also decreased in patients suffering from ALS $[29,58]$. Therefore, ALS may have to be considered a more complex disease than just being defined by one single parameter.

Soy contains the steroidal isoflavones genistein and daidzein, which are selective ERß-agonistic solutes and are structurally similar to steroidal ADIOLS [24, 26]. Therefore they fall into the category of solutes recommended by other researchers as potential candidates for treatment of ALS and, additionally, are structurally and pharmacologically similar to ADIOL [77]. FSWW08, a specially fermented soy formulation has been proven to increase ADIOL in other studies, besides the fact it contains isoflavones, which are structurally similar to ADIOL [28]. FSWW08 has been shown in other studies to significantly improve immunity in cancer, severe mental disease [24, 28]. FSWW08 improves triglycerides (Figure 3), which has not been reported with normal soy, although soy has a general health claim for reducing cardiovascular risk (Table 2).

Increased blood marker normally linked to metabolic disease are not only a sign of cellular stress and inflammation in obesity, but also in severe diseases like cancer, severe inflammations, lupus, and severe infections (Table 3) [59, 60, 62]. Recently published studies on Western and Japanese patients indicated that serum levels of triglyceride, LDL, cholesterol were correlated with clinical deterioration in ALS patients (Figure 1) [30]: Metabolic and nutritional conditions of lipid, urate and iron could contribute to disease progression and severity of ALS [30]. There are,

Table 3: List of severe diseases in which dyslipidemia is a sign of that disease or even a marker of severity of the disease. Please note that the number of publication in all areas are substantial and examples are only cited to demonstrate the general significance

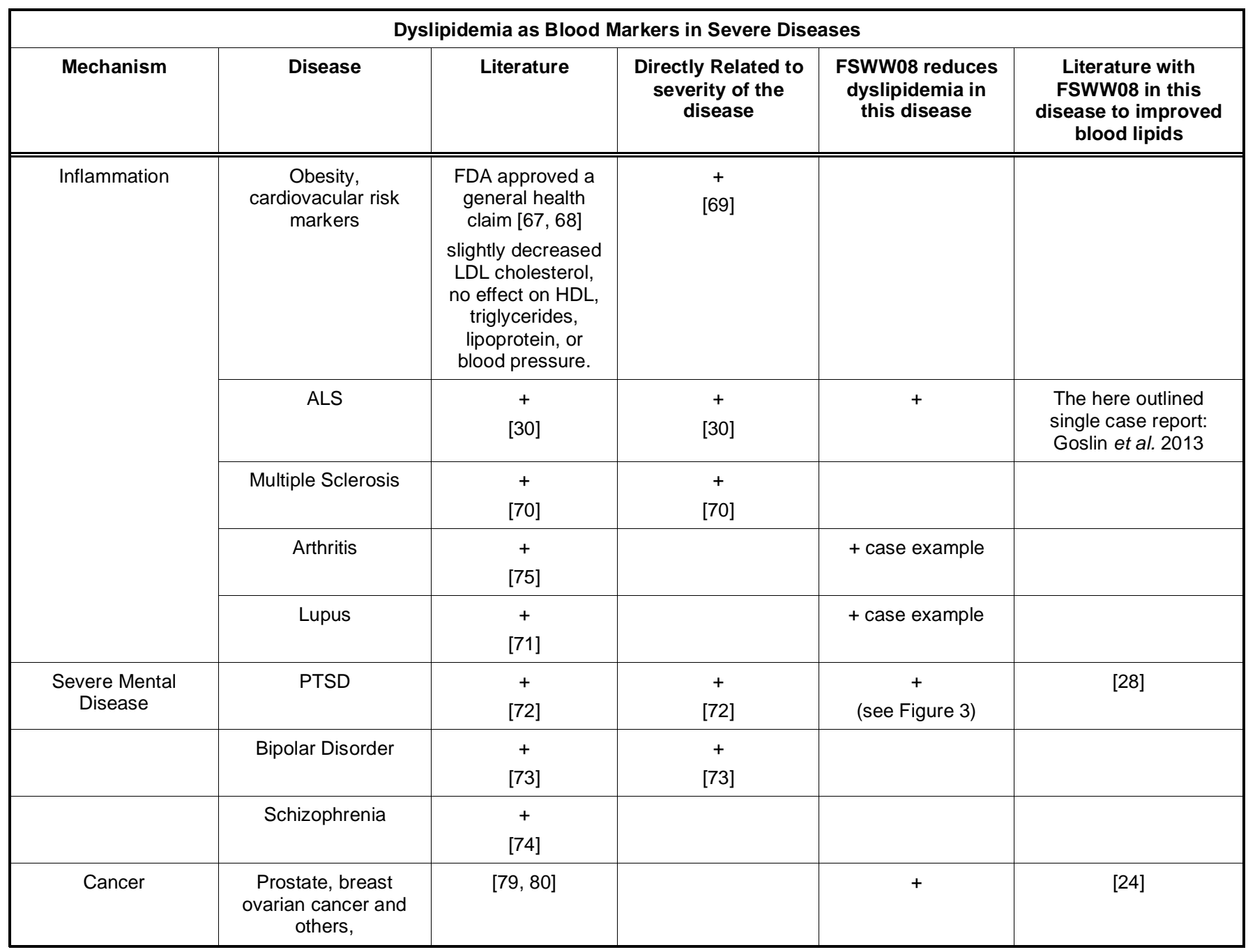


however, also studies published, that survival is related to increased blood lipids [63]. Survival or severity of ALS show two different parameter, because ALS patients at the end of their life seem to be rather cachectic. Long periods of starvation reduce blood lipids [65], rather than being directly related to ALS. FSWW08 has shown in clinical trials with soldiers suffering from posttraumatic stress disorders a remarkable reduction of triglycerides, cholesterol, LDL and increase in HDL (Figure 3) [28]. Since soy has an unspecific health claim for slightly improving cholesterol and LDL in general nutrition [67, 68], however shows no improvement in triglycerides and in HDL, it has been discussed by experts, that different methods of fermentation, particularly those leading to FSWW08, leads to different immune modifying abilities and may therefore modify blood lipids and stress in severe diseases, surpassing those in normal nutritional products [76].

Nevertheless, this paper cannot elucidate whether blood lipids are a relevant marker for ALS. A study with a larger cohort suffering from ALS consuming FSWW08 is warranted to investigate whether these results can be corroborated.

\section{ACKNOWLEDGEMENT}

The authors wish to express their deepest respect to Dr. Norman Ho, a former Professor of Pharmaceutics from the University of Michigan, who developed Models for biological and medical systems, when standardized findings may, or may not be transferred into other clinical situations. Without his pioneering work and leadership, the here outlined findings would not have been possible.

\section{REFERENCES}

[1] Amyotrophic lateral sclerosis. Wikipedia.http://en.wikipedia. org/wiki/Amyotrophic_lateral_sclerosis

[2] Pratt AJ, Getzoff ED, Perry JJ. Amyotrophic lateral sclerosis: update and new developments. Degener Neurol Neuromuscul Dis 2012; 2012(2): 1-14.

[3] Martin LJ, Price AC, Kaiser A, Shaikh AY, Liu Z. Mechanisms for neuronal degeneration in amyotrophic lateral sclerosis and in models of motor neuron death (Review). Int $\mathrm{J}$ Mol Med 2000; 5(1): 3-13.

[4] Siddique T, Hu P, Hentati A, Deng G, Hung WY, Mclnnis $M G$, et al. A molecular genetic approach to amyotrophic lateral sclerosis. Int J Neurol 1991-1992; 25-26: 60-9.

[5] Wijesekera LC, Leigh PN. Amyotrophic lateral sclerosis. Orphanet J Rare Dis 2009; 4: 3. http://dx.doi.org/10.1186/1750-1172-4-3

[6] Ince PG, Tomkins J, Slade JY, Thatcher NM, Shaw PJ. Amyotrophic lateral sclerosis associated with genetic abnormalities in the gene encoding $\mathrm{Cu} / \mathrm{Zn}$ superoxide dismutase: molecular pathology of five new cases, and comparison with previous reports and 73 sporadic cases of ALS. J Neuropathol Exp Neurol 1998; 57(10): 895-904. http://dx.doi.org/10.1097/00005072-199810000-00002

[7] Ferraiuolo L, Kirby J, Grierson AJ, Sendtner M, Shaw PJ. Molecular pathways of motor neuron injury in amyotrophic lateral sclerosis. Nat Rev Neurol 2011; 7(11): 616-30. http://dx.doi.org/10.1038/nrneurol.2011.152

[8] Sta M, Sylva-Steenland RM, Casula M, de Jong JM, Troost $D$, Aronica $E$, Baas F. Innate and adaptive immunity in amyotrophic lateral sclerosis: evidence of complement activation. Neurobiol Dis 2011; 42(3): 211-20.

http://dx.doi.org/10.1016/j.nbd.2011.01.002

[9] Khandelwal PJ, Herman AM, Moussa CE. Inflammation in the early stages of neurodegenerative pathology. J Neuroimmunol 2011; 238(1-2): 1-11.

http://dx.doi.org/10.1016/i.jneuroim.2011.07.002

[10] Moviglia GA, Varela G, Gaeta CA, Brizuela JA, Bastos F, Saslavsky $\mathrm{J}$. Autoreactive $\mathrm{T}$ cells induce in vitro $\mathrm{BM}$ mesenchymal stem cell transdifferentiation to neural stem cells. Cytotherapy 2006; 8(3): 196-201.

http://dx.doi.org/10.1080/14653240600735958

[11] Finkelstein A, Kunis G, Seksenyan A, Ronen A, Berkutzki T, Azoulay D, et al. Abnormal changes in NKT cells, the IGF-1 axis, and liver pathology in an animal model of ALS. PLoS One 2011; 6(8): e22374. http://dx.doi.org/10.1371/journal.pone.0022374

[12] Akhvlediani T, Kvirkvelia N, Shakarishvili R, Tsertsvadze T. Als-like syndrome in the patient with chronic hepatitis $\mathrm{C}$. Georgian Med News 2009; (172-173): 70-2.

[13] Miana-Mena FJ, González-Mingot C, Larrodé P, Muñoz MJ, Oliván S, Fuentes-Broto $\mathrm{L}$, et al. Monitoring systemic oxidative stress in an animal model of amyotrophic lateral sclerosis. J Neurol 2011; 258(5): 762-9.

http://dx.doi.org/10.1007/s00415-010-5825-8

[14] Galan L, Gomez-Pinedo U, Vela-Souto A, Guerrero-Sola A Barcia JA, Gutierrez AR, et al. Subventricular zone in motor neuron disease with frontotemporal dementia. Neurosci Lett 2011; 499(1): 9-13. http://dx.doi.org/10.1016/j.neulet.2011.05.019

[15] O'Reilly EJ, Wang H, Weisskopf MG, Fitzgerald KC, Falcone $\mathrm{G}$, McCullough ML, et al. Premorbid body mass index and risk of amyotrophic lateral sclerosis. Amyotroph Lateral Scler Frontotemporal Degener 2012 Oct 29. [Epub ahead of print].

[16] Turner MR, Wotton C, Talbot K, Goldacre MJ. Cardiovascular fitness as a risk factor for amyotrophic lateral sclerosis: indirect evidence from record linkage study. J Neurol Neurosurg Psychiatry 2012; 83(4): 395-8. http://dx.doi.org/10.1136/jnnp-2011-301161

[17] Moreau C, Brunaud-Danel V, Dallongeville J, Duhamel A, Laurier-Grymonprez L, de Reuck J, et al. Modifying effect of arterial hypertension on amyotrophic lateral sclerosis. Amyotroph Lateral Scler 2012; 13(2): 194-201. http://dx.doi.org/10.3109/17482968.2011.610110

[18] Ikeda K, Hirayama T, Takazawa T, Kawabe K, Iwasaki Y. Intern Med. Relationships between disease progression and serum levels of lipid, urate, creatinine and ferritin in Japanese patients with amyotrophic lateral sclerosis: a crosssectional study 2012; 51(12): 1501-8.

[19] Bungener C. Emotions and amyotrophic lateral sclerosis: a psychopathological perspective. Geriatr Psychol Neuropsychiatr Vieil 2012; 10(1): 57-64.

[20] Praline J, Vourc'h P, Guennoc AM, Veyrat-Durebex C, Corcia $P$. Co-occurrence of progressive anarthria with an S393L TARDBP mutation and ALS within a family. Amyotroph Lateral Scler 2012; 13(1): 155-7. http://dx.doi.org/10.3109/17482968.2011.598168

[21] Fang F, Chen H, Wirdefeldt K, Ronnevi LO, Al-Chalabi A, Peters TL, et al. Infection of the central nervous system, sepsis and amyotrophic lateral sclerosis. PLoS One 2011; 6(12): e29749. PLoS One 2011; 6(12): e29749.

http://dx.doi.org/10.1371/journal.pone.0029749 
[22] Kim DS, Kim JY, Han Y. Curcuminoids in neurodegenerative diseases. Recent Pat CNS Drug Discov 2012; 7(3): 184-204. http://dx.doi.org/10.2174/157488912803252032

[23] Kastenholz B, Garfin DE. Medicinal plants: a natural chaperones source for treating neurological disorders. Protein Pept Lett 2009; 16(2): 116-20.

http://dx.doi.org/10.2174/092986609787316234

[24] Rohr UD, Li WW, Ziqiang H, Wainright W, Schindler AE. The effect of fermented soy (FSWW08) on blood hematology and cachexia in cancer patients. Horm Mol Biol Clin Invest 2012. http://dx.doi.org/10.1515/hmbci-2012-0028

[25] Jacob U, Gocan A, Bachg D, Rohr UD. Applikation von fermentierter Soja bei Krebspatienten zur Verminderung von Kachexieund Erhöhung der Apoptose - eine prospektive Pilotstudie. J Gynecol Endokrinol 2009; 19: 18-28.

[26] Gocan AG, Bachg D, Schindler AE, Rohr UD. Managing immunity in resistant cancer patients correlates to survival: resultsand discussion of a pilot study. Horm Mol Biol Clin Invest 2011; 8: 455-69.

[27] Rohr UD, Gocan AG, Bachg D, Schindler AE. Cancer protection ofsoy resembles cancer protection duringpregnancy. Horm Mol Biol Clin Invest 2010; 3: 391409.

[28] Gocan AG, Bachg D, Schindler AE, Rohr UD. Balancing steroidal hormone cascade in treatment-resistant veteran soldiers with PTSD using a fermented soy product (FSWW08): a pilot study. Horm Mol Biol Clin Invest 2012; 10: 301-14.

[29] Roozendaal B, Kim S, Wolf OT, Kim MS, Sung KK, Lee S. The cortisol awakening response in amyotrophic lateral sclerosis is blunted and correlates with clinical status and depressive mood. Psychoneuroendocrinology 2012; 37(1): 20-6. http://dx.doi.org/10.1016/j.psyneuen.2011.04.013

[30] Ikeda K, Hirayama T, Takazawa T, Kawabe K, Iwasaki Y. Relationships between disease progression and serum levels of lipid, urate, creatinine and ferritin in Japanese patients with amyotrophic lateral sclerosis: a cross-sectional study. Intern Med 2012; 51(12): 1501-8.

http://dx.doi.org/10.2169/internalmedicine.51.7465

[31] Zoccolella S, Simone IL, Capozzo R, et al. An exploratory study of serum urate levels in patients with amyotrophic lateral sclerosis. J Neurol 2011; 258: 238-43.

http://dx.doi.org/10.1007/s00415-010-5735-9

[32] Qureshi M, Brown RH Jr, Rogers JT, Cudkowicz ME. Serum ferritin and metal levels as risk factors for amyotrophic lateral sclerosis. Open Neurol J 2008; 2: 51-54.

[33] Goodall EF, Haque MS, Morrison KE. Increased serum ferritin levels in amyotrophic lateral sclerosis (ALS) patients. J Neurol 2008; 255: 1652-56. http://dx.doi.org/10.1007/s00415-008-0945-0

[34] Qureshi M, Cudkowicz ME, Schoenfeld D, et al. Elevated serum ferritin levels correlate with faster disease course in ALS. Neurology 2009; 72(Suppl. 3): A418.

[35] Mitchell RM, Simmons Z, Beard JL, Stephens H, Connor JR. Plasma biomarkers associated with ALS and their relationship toiron homeostasis. Muscle Nerve 2010; 42: 95103.

http://dx.doi.org/10.1002/mus.21625

[36] Paganoni S, Deng J, Jaffa M, Cudkowicz ME, Wills AM. Body mass index, not dyslipidemia, is an independent predictor of survival in amyotrophic lateral sclerosis. Muscle Nerve 2011; 44: $20-24$. http://dx.doi.org/10.1002/mus.22114

[37] Brooks BR, Miller RG, Swash M, Munsat TL. World federation of neurology research group on motor neuron diseases. El Escorial revisited: revised criteria for the diagnosis of amyotrophic lateral sclerosis. Amyotroph Lateral Scler Other Motor Neuron Disord 2000; 1: 293-99.

http://dx.doi.org/10.1080/146608200300079536
[38] Jackson IMD. Effect of prolonged starvation on blood lipid levels of obese subjects. Metabolism 1969; 18: 13-17. http://dx.doi.org/10.1016/0026-0495(69)90128-0

[39] Suzuki H, Matsuoka M. The JNK/C-Jun signaling axis contributes to the TDP-43-induced cell death. Mol Cell Biochem 2012; [Epub ahead of print].

[40] Ikenaka K, Katsuno M, Kawai K, Ishigaki S, Tanaka F, Sobue G. Disruption of axonal transport in motor neuron diseases. Int J Mol Sci 2012; 13(1): 1225-38. http://dx.doi.org/10.3390/ijms13011225

[41] Meyerowitz J, Parker SJ, Vella LJ, Ng DCh, Price KA, Liddell $\mathrm{JR}$, et al. C-Jun N-terminal kinase controls TDP-43 accumulation in stress granules induced by oxidative stress. Mol Neurodegener 2011; 6: 57. http://dx.doi.org/10.1186/1750-1326-6-57

[42] Hossaini M, Cardona Cano S, van Dis V, Haasdijk ED, Hoogenraad CC, Holstege JC, et al. Spinal inhibitory interneuron pathology follows motor neuron degeneration independent of glial mutant superoxide dismutase 1 expression in SOD1-ALS mice. J Neuropathol Exp Neurol 2011; 70(8): 662-77.

http://dx.doi.org/10.1097/NEN.0b013e31822581ac

[43] Seldeen KL, McDonald CB, Deegan BJ, Bhat V, Farooq A Dissecting the role of leucine zippers in the binding of bZIP domains of Jun transcription factor to DNA. Biochem Biophys Res Commun 2010; 394(4): 1030-5. http://dx.doi.org/10.1016/j.bbrc.2010.03.116

[44] Kim EK, Choi EJ. Pathological roles of MAPK signaling pathways in human diseases. Biochim Biophys Acta 2010; 1802(4): 396-405. http://dx.doi.org/10.1016/j.bbadis.2009.12.009

[45] Klein A, He X, Roche M, Mallett A, Duska L, Supko JG, et al. Prolonged stabilization of platinum-resistant ovarian cancer in a single patient consuming a fermented soy therapy. Gynecol Oncol 2006; 100(1): 205-9.

http://dx.doi.org/10.1016/j.ygyno.2005.08.006

[46] Rudrabhatla P, Albers W, Pant HC. Peptidyl-prolyl isomerase 1 regulates protein phosphatase $2 \mathrm{~A}$-mediated topographic phosphorylation of neurofilament proteins. J Neurosci 2009; 29(47): 14869-80.

http://dx.doi.org/10.1523/JNEUROSCI.4469-09.2009

[47] Wojda I. MAP kinase pathways--their evolution and role in some neurodegenerative diseases. Postepy Biochem 2012; 58(1): 79-90.

[48] Freedman DM, Curtis RE, Daugherty SE, Goedert JJ, Kunc RW, Tucker MA. The association between cancer and amyotrophic lateral sclerosis. Cancer Causes Control 2013; 24(1): 55-60.

http://dx.doi.org/10.1007/s10552-012-0089-5

[49] Tanaka F, Niwa J, Ishigaki S, Katsuno M, Waza M, Yamamoto $\mathrm{M}$, et al. Gene expression profiling toward understanding of ALS pathogenesis. Ann NY Acad Sci 2006; 1086: $1-10$.

http://dx.doi.org/10.1196/annals.1377.011

[50] Kudo LC, Parfenova L, Vi N, Lau K, Pomakian J, Valdmanis $\mathrm{P}$, et al. Integrative gene-tissue microarray-based approach for identification of human disease biomarkers: application to amyotrophic lateral sclerosis. Hum Mol Genet 2010; 19(16): 3233-53.

http://dx.doi.org/10.1093/hmg/ddq232

[51] Ringer C, Weihe E, Schütz B. Calcitonin gene-related peptide expression levels predict motor neuron vulnerability in the superoxide dismutase 1-G93A mouse model of amyotrophic lateral sclerosis. Neurobiol Dis 2012; 45(1): 54754. http://dx.doi.org/10.1016/j.nbd.2011.09.011

[52] Cedarbaum JM, Stambler N, Malta E, Fuller C, Hilt D, Thurmond B, et al. The ALSFRS-R: a revised ALS functional rating scale that incorporates assessments of respiratory 
function. BDNF ALS Study Group (Phase III). J Neurol Sci 1999; 169(1-2): 13-21.

http://dx.doi.org/10.1016/S0022-510X(99)00210-5

[53] Raaphorst J, Beeldman E, Schmand B, Berkhout J, Linssen $\mathrm{WH}$, van den Berg $\mathrm{LH}$, et al. The ALS-FTD-Q: a new screening tool for behavioral disturbances in ALS. Neurology 2012; 79(13): 1377-83.

http://dx.doi.org/10.1212/WNL.0b013e31826c1aa1

[54] Ravasco P, Monteiro-Grillo I, Marques Vidal P, Camilo ME. Impact of nutrition on outcome: a prospective randomized controlled trial in patients with head and neck cancer undergoing radiotherapy. Head Neck 2005; 27(8): 659-68. http://dx.doi.org/10.1002/hed.20221

[55] Swanney MP, Ruppel G, Enright PL. Using the lower limit of normal for the FEV1/FVC ratio reduces the misclassification of airway obstruction. Thorax 2008; 63(12): 1046-51. http://dx.doi.org/10.1136/thx.2008.098483

[56] Sahebjami H, Gartside PS. Pulmonary function in obese subjects with a normal FEV1/FVC ratio. Chest 1996; 110(6): 1425-9.

http://dx.doi.org/10.1378/chest.110.6.1425

[57] Mac Sweeney R, McAuley DF, Matthay MA. Acute lung failure. Semin Respir Crit Care Med 2011; 32(5): 607-25. http://dx.doi.org/10.1055/s-0031-1287870

[58] Militello A, Vitello G, Lunetta C, Toscano A, Maiorana G, Piccoli $\mathrm{T}$, et al. The serum level of free testosterone is reduced in amyotrophic lateral sclerosis. J Neurol Sci 2002; 195(1): 67-70.

http://dx.doi.org/10.1016/S0022-510X(01)00688-8

[59] Fowler B. Homocystein--an independent risk factor for cardiovascular and thrombotic diseases. Ther Umsch 2005; 62(9): 641-6. http://dx.doi.org/10.1024/0040-5930.62.9.641

[60] Klack K, Bonfa E, Borba Neto EF. Diet and nutritional aspects in systemic lupus erythematosus. Rev Bras Reumatol 2012; 52(3): 384-408.

[61] Ceprnja M, Derek L, Unić A, Blazev M, Fistonić M, KozarićKovacić $D$, et al. Oxidative stress markers in patients with post-traumatic stress disorder. Coll Antropol 2011; 35(4): 1155-60.

[62] Yang Y, Mauldin PD, Ebeling M, Hulsey TC, Liu B, Thomas $\mathrm{MB}$, et al. Effect of metabolic syndrome and its components on recurrence and survival in colon cancer patients. Cancer 2012. http://dx.doi.org/10.1002/cncr.27923

[63] Albert SM. Dyslipidemia in ALS: good, bad, or unclear? Neurology 2008; 70(13): 988-9. http://dx.doi.org/10.1212/01.wnl.0000306636.61882.42

[64] Lisch HJ, Bolzano K, Herbst M, Sailer S, Sandhofer F, Braunsteiner $\mathrm{H}$. Effect of body weight changes on plasma lipids in patients with primary hyperlipoproteinemia. Atherosclerosis $1974 ; 19(3)$ : 477-84. http://dx.doi.org/10.1016/S0021-9150(74)80013-4

[65] Dattilo AM, Kris-Etherton PM. Effect of body weight changes on plasma lipids-A metaanalysis. Am J Clin Nutr 1992; 56: 308-14.

[66] Loria RM. Immune up-regulation and tumor apoptosis by androstene steroids. Steroids 2002; 67(12): 953-66. http://dx.doi.org/10.1016/S0039-128X(02)00043-0
[67] Xiao CW. Health effects of soy protein and isoflavones in humans. J Nutr 2008; 138(6): 1244S-9S.

[68] Ma L, Grann K, Li M, Jiang Z. A pilot study to evaluate the effect of soy isolate protein on the serum lipid profile and other potential cardiovascular risk markers in moderately hypercholesterolemic Chinese adults. Ecol Food Nutr 2011; 50(6): 473-85.

http://dx.doi.org/10.1080/03670244.2011.620875

[69] Cubeddu LX, Hoffmann IS. Metabolic syndrome: an all or none or a continuum load of risk? Metab Syndr Relat Disord 2012; 10(1): 14-9.

http://dx.doi.org/10.1089/met.2011.0058

[70] Weinstock-Guttman B, Zivadinov R, Mahfooz N, Carl E, Drake A, Schneider J, et al. Serum lipid profiles are associated with disability and MRI outcomes in multiple sclerosis. J Neuroinflammation 2011; 8: 127. http://dx.doi.org/10.1186/1742-2094-8-127

[71] Klack K, Bonfa E, Borba Neto EF. Diet and nutritional aspects in systemic lupus erythematosus. Rev Bras Reumatol 2012; 52(3): 384-408.

[72] Von Känel R, Kraemer B, Saner H, Schmid JP, Abbas CC, Begré S. Posttraumatic stress disorder and dyslipidemia: previous research and novel findings from patients with PTSD caused by myocardial infarction. World $\mathrm{J}$ Biol Psychiatry 2010; 11(2): 141-7. http://dx.doi.org/10.3109/15622970903449846

[73] Soreca I, Wallace ML, Frank E, Hasler BP, Levenson JC Kupfer DJ. Sleep duration is associated with dyslipidemia in patients with bipolar disorder in clinical remission. J Affect Disord 2012; 141(2-3): 484-7. http://dx.doi.org/10.1016/i.jad.2012.01.046

[74] Watanabe J, Suzuki Y, Someya T. Lipid effects of psychiatric medications. Curr Atheroscler Rep 2013; 15(1): 292.

http://dx.doi.org/10.1007/s11883-012-0292-6

[75] Păstrăiguş C, Ancuţa C, Miu S, Ancuţa E, Chirieac R. Knee osteoarthritis, dyslipidemia syndrome and exercise. Rev Med Chir Soc Med Nat lasi 2012; 116(2): 481-6.

[76] Wainright WH. Not all soy products are created equal: interpretation of research results diffi cult. Townsend Lett 2008; 16: 487-96.

[77] Saijo K, Collier JG, Li AC, Katzenellenbogen JA, Glass CK An ADIOL-ER $\beta$-CtBP transrepression pathway negatively regulates microglia-mediated inflammation. Cell 2011; 145: 584-95. http://dx.doi.org/10.1016/i.cell.2011.03.050

[78] Norata GB, Cattaneo P, Poletti A, Catapano AL. The androgen derivative 5alpha-androstane-3beta,17-diol inhibits tumor necrosis factor alpha and lipopolysaccharide induced inflammatory response in human endothelial cells and in mice aorta. Artheriosclerosis 2010; 212: 100-106.

[79] Esposito K, Chiodinin P, Capuano A, Belasstella G, Majorino $\mathrm{MI}$, Paretta $\mathrm{E}$, et al. Effect of metabolic syndrome and its components on prostate cancer risk: Meta-analysis. Endocrinol Invest 2013; 36: 132-9.

[80] Yang Y, Mauldin PD, Ebeling M, Hulsey TC, Liu B, Thomas $\mathrm{MB}$, et al. Effect of metabolic syndrome and its components on recurrence and survival in colon cancer patients. Cancer 2012.

http://dx.doi.org/10.1002/cncr.27923

\section{DOI: http://dx.doi.org/10.6000/1929-5634.2013.02.01.2}

(c) 2013 Goslin et al.; Licensee Lifescience Global.

This is an open access article licensed under the terms of the Creative Commons Attribution Non-Commercial License (http://creativecommons.org/licenses/by-nc/3.0/) which permits unrestricted, non-commercial use, distribution and reproduction in any medium, provided the work is properly cited. 